УДК 78.071.1:780.616.432:78.087.34 “18-19”

DOI: https://doi.org/10.33643/kmus.2019.59.04

Євген Дашак, старший викладач кафедри спеціального фортепіано № 2, провідний конщертмейстер, здобувач кафедри історії світової музики

Національної музичної академї України ім. П. І. Чайковського https://orcid.org/0000-0002-1016-4311

dashevgen@ukr.net

Yevhen Dashak,

Senior Lecturer at the Department of Special Piano № 2, Lead Accompanist, Applicant at the History of World Music Department, Ukrainian National Tchaikovsky academy of music https://orcid.org/0000-0002-1016-4311 dashevgen@ukr.net

\title{
«РАПСОДІЯ», «СКЕРЦО» ТА «БАЛАДА» ДЛЯ ФОРТЕПІАННОГО КВАРТЕТУ ЙОЗЕФА МАРКСА: ПІЗНЬОРОМАНТИЧНІ ПРИНЦИПИ ФОРМОУТВОРЕННЯ
}

У статті розглянуто «Рапсодію», «Скерцо» та «Баладу» для фортепіанного квартету австрійського композитора Йозефа Маркса (18821964). Проаналізовані стильові та світоглядні зв'язки даного твору з пізнім романтизмом. Встановлено, що всі три частини утворюють єдиний камерно-інструментальний цикл: об'єднавчими факторами виступають інтонаційно-драматургічні зв'язки, а також прийом синтезування стильових елементів різних музично-історичних епох. Так, в «Рапсодії» перевтілені основні риси симфонічних поем Ф. Ліста, «Скерцо» та «Балада» синтезують елементи романтичного скерцо, бахівської поліфонії та побутової музики Відня. Виявлені риси індивідуального стилю Й. Маркса, серед яких - епічні масштаби композиції, вишукана гармонічна мова, майстерне володіння ансамблевою фактурою.

Ключові слова: фортепіанний квартет, рапсодія, скерцо, балада, пізній романтизм.

Dashak Yevhen. «Rhapsody», «Scherzo» and «Ballad» for the Piano Quartet by Joseph Marx: late-romantic principles of formation. There are considered the chamber works of Josef Marx (1882-1964), an Austrian composer, theorist, critic, teacher, pianist, and social and cultural activist. The basis of the creative worldview of J. Marx was loyalty to the ideals of high art of past eras. The composer created musicological theory, confirming the firmness of the laws of tonality in consciousness, perception and psychology.

The relevance of the study is connected with the need to deepen the problems of late romanticism, which is still insufficiently studied in Ukrainian 
musicology, and with the need to familiarize musicians with little-known piece that can enrich the chamber-instrumental repertoire. The main objective of this study is to analyze the Piano Quartet in three parts («Rhapsody», «Scherzo» and «Ballad», 1911) in terms of its links with late romanticism.

In various musicological sources, J. Marx appears as a «late romantic», «late romantic (or postromantic) impressionist», «neo-romantic», «romantic realist». The genetic connection of his work with the period of late romanticism, which somehow coincides with the formation and flowering of modernism, is absolutely obvious. The combination of the traditional and the new, characteristic of the works of art of the «crucial» period of the beginning of the twentieth century, is the focus of the analysis of the «Rhapsody», "Scherzo» and «Ballad» for the piano quartet. The research methodology consists of using the analytical and historical methods; also analysis is based on the concept of typology of the later stages in the history of art by L. Nebolyubova.

The scientific novelty of the study consists in examining such a large chamber-instrumental work as the Piano Quartet of J. Marx from the point of view of his stylistic connections with late romanticism. "Rhapsody» in A-dur, «Scherzo» in d-moll and «Ballad» in a-moll for the piano quartet form a largescale chamber-instrumental cycle, which in its outlines resembles rather a symphonic work. All three parts form a single line of dramatic development. Each part is related to a large, significant instrumental genre of musical romanticism.

A significant achievement of J. Marx is the unification of the three parts into a single apartment cycle using intonational and thematic connections: the universal source of most of the Scherzo and Ballad themes is the thematicism of Rhapsody, which contains the epic (recitative), lyrical (romance) and scherzo (dance) origins.

«Rhapsody» is a kind of «dedication» to F. Liszt, the creator of the romantic instrumental rhapsody. The uniqueness of the «Rhapsody» is the embodiment of this genre, originally in Liszt's creation intended for solo performance, in the form of an instrumental quartet. From the point of view of genre and composition «Rhapsody» by J. Marx is the chamber-instrumental analogue of a symphonic poem. Here the composer consistently applies the principle of monothematicism: the intonation and genre multi-faceted theme of the main part is the source of absolutely all the themes of the quartet. An interesting method is the peculiar «re-testing» of the chamber ensemble, which is entrusted with various types of virtuoso piano texture.

The Scherzo rondal composition is based on a contrasting alternation of two themes: a lively, playful, somewhat impressionistic scherzo and a strict, monolithic unison theme. In «Scherzo» J. Marx freely operates with different- 
style elements from Bach's polyphony and virtuoso romantic scherzo to AustroGerman Lied and the «applied» music of a Viennese coffee house.

«Ballad» is written in the «classic» sonata form and performs the function of a slow part and a philosophical epilogue. It most fully embodies the deep connections of Josef Marx's art with the art of baroque and classicism: this is evidenced by the clarity and clarity of the composition, the contrasting figurative and semantic combination of the main and secondary parts traditional for the sonata form, the wide use of the techniques of polyphonic and tune development. With the romantic genre of the ballad, the work of J. Marx combines the epic narrative tone and the unhurriedness of the dramatic unfolding.

Findings. The final, synthetic nature of late romanticism was embodied in the Piano Quartet by J. Marx in the free operation of elements of various musical styles. At the same time, the composer manages to avoid the impression of eclecticism and bad taste: a powerful «common denominator» is his bright individual style. The performance of the Piano Quartet is a challenge for any ensemble, since the main difficulty lies primarily in the intellectual comprehension of its multi-syllable composition - externally heterogeneous, asymmetric, but at the same time covered by iron logic.

Key words: piano quartet, rhapsody, scherzo, ballad, late romanticism.

Дашак Свгений. «Рапсодия", «Скерцо» и «Баллада» для фортепианного квартета Йозефа Маркса: позднеромантические принципы формообразования. В статье рассмотрено камерноинструментальное творчество Йозефа Маркса (1882-1964) - австрийского композитора, теоретика, критика, педагога, пианиста и общественнокультурного деятеля. Основой творческого мировоззрения Й. Маркса была верность идеалам высокого искусства прошедших эпох. Композитор создал музыковедческую теорию, подтверждающую стойкость законов тональности в сознании, восприятии и психологии.

Актуальность статьи связана с необходимостью углубления проблематики позднего романтизма, все еще недостаточно исследованного в отечественном музыкознании, а также с потребностью ознакомления музыкантов-исполнителей с малоизвестным произведением, способным обогатить камерно-инструментальный репертуар. Основной задачей данного исследования является анализ Фортепианного квартета в трех частях («Рапсодия», «Скерцо» и «Баллада», 1911) с точки зрения его связей с поздним романтизмом.

В различных музыковедческих источниках Й. Маркс фигурирует как «поздний романтик», «позднеромантический (или постромантический) 
импрессионист», «неоромантик», «романтический реалист». Абсолютно очевидна генетическая связь его творчества с периодом позднего романтизма, который, так или иначе, совпадает с формированием и расцветом модернизма. Сочетание традиционного и нового, характерное для произведений искусства «переломного» периода начала XX века, находится в центре внимания анализа «Рапсодии», «Скерцо» и «Баллады» для фортепианного квартета. Работа опирается на аналитический метод исследования, а также на концепцию типологии поздних этапов в истории искусства Л. Неболюбовой.

Научная новизна исследования состоит в рассмотрении такого крупного камерно-инструментального произведения, как Фортепианный квартет Й. Маркса, с точки зрения его стилевых связей с поздним романтизмом. «Рапсодия» A-dur, «Скерцо» d-moll и «Баллада» a-moll для фортепианного квартета образуют собой масштабный камерноинструментальный цикл, который своими очертаниями напоминает скорее симфоническое произведение. Все три части формируют единую линию драматургического развития. Каждая часть родственна большому, знаковому инструментальному жанру музыкального романтизма. Значительным достижением Й. Маркса является объединение трех частей в единый квартетный цикл с помощью интонационно-тематических связей: универсальным источником большинства тем «Скерцо» и «Баллады» является тематизм «Рапсодии», который содержит в себе эпикоречитативное, лирико-романсовое и скерцозно-танцевальное начала.

«Рапсодия» является своеобразным «посвящением» Ф. Листу создателю романтической инструментальной рапсодии. Уникальность «Рапсодии» заключается в воплощении этого жанра, изначально в творчестве Листа предназначенного для сольного исполнения, в форме инструментального квартета. С жанрово-композиционной точки зрения «Рапсодия» Й. Маркса является камерно-инструментальным аналогом симфонической поэмы. Здесь композитор последовательно применяет листовский принцип монотематизма: интонационно и жанрово многогранная тема главной партии выступает источником абсолютно всех тем квартета. Интересен прием своеобразной «переоркестровки» камерного ансамбля, которому поручаются различные типы виртуозной фортепианной фактуры.

Рондальная композиция «Скерцо» основана на контрастном чередовании двух тем-образов: живого, игривого, несколько импрессионистического скерцо и строгой, монолитной унисонной темы. В «Скерцо» Й. Маркс свободно оперирует разностилевыми элементами от 
баховской полифонии и виртуозного романтического скерцо до австронемецкой Lied и «прикладной» музыки венской кофейни.

«Баллада» написана в «классической» сонатной форме и выполняет функцию медленной части и философского эпилога. Она наиболее полно воплощает в себе глубинные связи творчества Йозефа Маркса с искусством барокко и классицизма: об этом свидетельствует четкость и ясность композиции, традиционное для сонатной формы контрастное образносмысловое сочетание главной и побочной партии, широкое использование приемов полифонического и мотивного развития. С романтическим жанром баллады произведение Й. Маркса объединяет эпическая повествовательность тона и неспешность драматургического развертывания.

Bbыводы. Заключительная, синтетическая природа позднего романтизма воплотилась в Фортепианном квартете Й. Маркса в свободном оперировании элементами различных музыкальных стилей. Исполнение Фортепианного квартета - непростая задача для любого ансамбля, поскольку основная сложность состоит, прежде всего, в интеллектуальном постижении его сложной композиции, внешне неоднородной и асимметричной, но при этом логичной и выверенной.

Ключевые слова: фортепианный квартет, рапсодия, скерцо, баллада, поздний романтизм.

Ім'я австрійського композитора Йозефа Маркса (1882-1964) нечасто зустрічається в роботах вітчизняних дослідників. Серед виконавців 3 його композиторською творчістю обізнані передусім вокалісти: Маркс $є$ автором близько 150 вокальних творів, що уславили його ім'я ще на початку композиторської кар'єри. Його Lied увійшли в історію австрійської та світової музичної культури разом з вокальними шедеврами Г. Вольфа, Г. Малера та Р. Штрауса. Для піаністів Й. Маркс є автором двох великих фортепіанних концертів: «Романтичний концерт» E-dur i Три п'єси для фортепіано з оркестром «Castelli Romani» залюбки включали до своїх програм такі відомі виконавці як В. Гізекінг та Ж. Боле. Яскравий цикл Й. Маркса «Шість п’єс для фортепіано» також може урізноманітнити концертний репертуар.

3 початку 2000-х років невпинно зростає інтерес до камерноінструментальної творчості Йозефа Маркса. 31999 по 2014 рік різними виконавцями були записані як ранні «Рапсодія», «Балада», «Скерцо» для фортепіанного квартету, так і більш пізні «Frühlingssonate» («Весняна соната») для скрипки і фортепіано D-dur та три струнні квартети 1930-х- 
1940-х років ${ }^{1}$ У грудні 2017 року автор цього дослідження разом із віолончелістом Антоном Страшновим-Пірським став першим виконавцем Сюїти для віолончелі та фортепіано Йозефа Маркса в Україні.

3 наукової точки зору інструментальна творчість Й. Маркса також становить значний інтерес для дослідників, адже композитор є яскравим представником кризового, перехідного етапу в історії західноєвропейської музики. Творчість Й. Маркса постала на зламі двох великих історикостильових епох романтизму та модернізму, риси яких повною мірою відбилися у його камерно-інструментальних опусах. Актуальність даного дослідження зумовлена необхідністю визначення тих аспектів, що поєднують творчість Й. Маркса 3 мистецьким минулим та сучасністю. Матеріалом дослідження обрано «Рапсодію», «Баладу» та «Скерцо» для фортепіанного квартету (1911): ці твори $€$ першим зверненням композитора до сфери камерно-інструментальної музики і втілюють індивідуальне, безпосереднє сприйняття 29-річним автором найбільш ключових, засадничих рис сучасної йому мистецької епохи. Наукова новизна публікації полягає у виявленні рис пізньоромантичного формоутворення на прикладі вкрай рідкісних камерно-інструментальних «версій» знакових романтичних жанрів рапсодії, балади та скерцо. Окрім того, «Рапсодія», «Балада» та «Скерцо» для фортепіанного квартету Й. Маркса ще ніколи не розглядалися вітчизняними музикознавцями. Власне, аналіз цих творів і $є$ головною метою даної публікації. Для цього застосовуватимуться методи інтонаційного-драматургічного та цілісного аналізу, що «враховує всі обставини - історичний контекст, стильові зв'язки (історичний, авторський стиль, напрямок), всі авторські позамузичні та музичні, жанрові асоціації» [11, с. 313].

Слід звернути увагу на філософсько-естетичні переконання Й. Маркса. За словами Берканта Хайдіна, як композитор «Маркс визначив свою відданість складним звуковим світам Макса Регера, Клода Дебюссі і Олександра Скрябіна $<\ldots .>$. Він ніколи не приховував свого захоплення отцями музики (Моцартом, Шуманом, Бахом, Гайдном та ін.)» [15]. Як професійний філософ та мистецтвознавець (у 1909 році Маркс з відзнакою закінчив філософський факультет університету Грацу), майстер все життя

\footnotetext{
1 У камерно-інструментальному доробку Й. Маркса - «Рапсодія», «Балада» і «Скерцо» для фортепіанного квартету (1911), Соната для скрипки та фортепіано A-dur (1913), «Тріо-фантазія» для скрипки, віолончелі та фортепіано (1914), Сюїта для віолончелі та фортепіано (1914), Струнний квартет $A$-dur (1937), «Хроматичний квартет» («Quartetto chromatico», 1936) «Квартет в античному дусі» («Quartetto in modo antico», 1938), «Квартет у класичному дусі» («Quartetto in modo classico», 1941), «Frühlingssonate» («Весняна соната») для скрипки і фортепіано D-dur (1945).
} 
обстоював вірність ідеалам високого мистецтва минулого і навіть створив музикознавчу теорію, що підтверджувала його переконання. Свої наукові досягнення він узагальнив у масштабній праці «Музика - універсальна мова» («Weltsprache Music», 1964). Так, в результаті досліджень Й. Маркс дійшов висновку, що закони тональності закладені у самій людській свідомості, сприйнятті та психології, що це своєрідний універсальний закон, порушення якого (тобто слідування атональності і додекафонії) суперечать законам мистецтва. Протягом життя він очолював так звану «старовіденську» школу, що протистояла нововіденській на чолі 3 А. Шенбергом, А. Бергом та ін. Варто зазначити, що на цьому шляху Й. Маркс слідував переконанням та творчому методу свого кумира М. Регера, який також «виступав за збереження тонального центру та класичної ладофункційної системи» [6, с. 27].

Загальну ідеологічну спрямованість всієї творчості Й. Маркса можна висловити словами М. Метнера - палкого шанувальника творчості митця: «Якщо варто взагалі окреслювати будь-які “проблеми” в мистецтві, то єдиною проблемою кожної його епохи має бути збереження спадкоємного зв'язку з великим минулим» [4, с. 419].

На даний момент чіткого визначення стильової приналежності творчості Й. Маркса все ще не існує. Б. Хайдін називає його «пізньоромантичним імпресіоністом» («late romantic impressionist») [15], а радянський дослідник Ю. Клусон - неоромантиком [5, с. 108]. А. Лісс вважає Й. Маркса одночасно «не лише романтиком, але й класиком» [17, с. 116], «пізнім романтиком», [17, с. 117] та «імпресіоністом» [17, с. 118]. К. Шлюрен розглядає Й. Маркса як «постромантичного імпресіоніста» [19, c. 12]. Одне з видань своїх критичних робіт сам Й. Маркс назвав «Роздуми романтичного реаліста» («Betrachtungen eines romantischen Realisten», 1947).

Основною причиною таких розбіжностей слід вважати, передусім, відсутність у зарубіжному та вітчизняному музикознавстві єдиної, універсальної концепції трактування мистецького періоду початку XX ст., що «охоплює пізньоромантичну стилістику, неофольклорні течії, париопозиції експресіонізм-неокласицизм, академізм-авангард <..>» [9, с. 87], тому «не буде перебільшенням стверджувати, що стилістична проблематика епохи в музиці XX ст. не тільки не може вважатися остаточно дослідженою в теоретичному плані, а й потребує пильної уваги» [9, с. 87]. Водночас 3 наведених вище визначень історико-стильової приналежності творчості Й. Маркса абсолютно очевидним є їі генетичний зв'язок з пізнім романтизмом, що так чи інакше збігається з періодом формування та розквіту модернізму. Поєднання традиційного і нового, 
властиве для творів мистецтва «зламного» періоду початку XX століття, буде в центрі уваги подальшого аналізу «Рапсодії», «Балади» та «Скерцо» для фортепіанного квартету Й. Маркса.

Вітчизняні та зарубіжні музикознавці виробили цілий ряд теорій музичного мистецтва початку XX століття. Серед найбільш відомих дослідження Т. Лєвої, Л. Неболюбової, Л. Русакової, О. Корчової, Л. Кияновської, П. Буркхолдера (P. Burkholder), К. Дальхауза (C. Dahlhaus), P. Тарускіна (R. Taruskin), Х. Паулса (H. Pauls) ${ }^{1}$ та ін. Даний аналіз спирається на концепцію типології пізніх етапів в історії мистецтва Л. Неболюбової. Дослідниця виокремлює такі загальні риси пізніх періодів, як «завершальний, підсумковий характер відносно історико-художнього “цілого”», «глибокий різнорівневий синтез», «суміщення функцій підсумкузамикання, зв’язки-переходу та передбачення» [7, с.67], «зовнішня видимість еклектичності», «обов’язкове визрівання в “еклектичному” системно-стильовому конгломераті елементів фактично нового», «загальна внутрішня напруженість та гіпертрофована нестабільність художньої системи» та «нестабільність світоглядного плану» [7, с. 68]. Означені тези покладені в основу подальшого аналізу творів Й. Маркса.

Отже, «Рапсодія» («Фортепіанний квартет у формі Рапсодії», «Klavierquartett in Form einer Rhapsodie»), «Скерцо» («Скерцо для фортепіанного квартету», «Scherzo für Klavierquartett») та «Балада» («Балада для фортепіано, скрипки, альта та віолончелі a-moll», «Ballade für Klavier, Violine, Viola und Violoncello in a-moll») для фортепіанного квартету утворюють масштабний камерно-інструментальний цикл ${ }^{2}$ з за словами дослідника К.Шлюрена, якби композитор «додав певний фінал, він сформував би чотиричастинний циикл, типу могутньої 80-хвилинної “симфоніі” для фортепіанного квартету» ${ }^{3}$ [19, с. 13]. Саме тому сучасними

\footnotetext{
${ }^{1}$ Означені концепції зарубіжних музикознавців проаналізовані в дисертаційному дослідженні німецького музикознавця канадського походження X. Паулса «Два століття в одному. Музичний романтизм та XX століття» (Herbert Pauls. «Two centuries in one. Musical Romanticism and the twentieth century», 2014) [18].

${ }^{2}$ Варто зазначити, що специфіку камерно-інструментального виконавства Йозеф Маркс знав «зсередини»: він був блискучим піаністом-акомпаніатором та все життя провадив активну концертну діяльність. Ще гімназистом він самостійно опанував скрипку та віолончель, а також організував власний квартет, для якого писав свої перші композиції.

${ }^{3}$ Якщо бути точним, то запис Фортепіанного квартету, здійснений у 2010 році О. Трендлом (Oliver Triendl, фортепіано), Д. Геде (Daniel Gaede, скрипка), Х. Шліхтігом (Hariolf Schlichtig, альт) та П. Брюнсом (Peter Bruns, віолончель) має тривалість 62 хв. Саме цей запис покладено в основу наведеного аналізу.
} 
дослідниками та виконавцями ці опуси сприймаються здебільшого як єдиний камерно-інструментальний цикл ${ }^{1}$. Багатолика й мінлива «Рапсодія», внутрішньо контрастне «Скерцо» та лірико-філософська «Балада» формують єдину лінію драматургічного розвитку. На користь цього трактування свідчать не лише одночасність написання (1911) та однорідність виконавського складу. Цілком очевидною $є$ спорідненість кожної з частин з великим, знаковим інструментальним жанром музичного романтизму (рапсодія, балада та скерцо) ${ }^{2}$. Як це буде очевидно 3 подальшого аналізу, всі три частини об'єднані потужними інтонаційними зв’язками, джерелом яких виступає головна тема «Рапсодії».

Яскравим зразком вишуканої інтелектуальної гри, шанобливого діалогу з прекрасним музичним минулим є Фортепіанний квартет у формі Рапсодії. Відповідно до жанрової назви, Й. Маркс замислив свій твір як своєрідну офіру Ф. Лісту - творцеві романтичної інструментальної рапсодії. Унікальність «Рапсодії» Й. Маркса полягає в перевтіленні цього жанру, початково у творчості Ф. Ліста призначеного для сольного виконання, у форму інструментального квартету. 3 лістівським жанровим прототипом опус Й. Маркса поєднують хіба що яскраві темпові співставлення та принцип чергування контрастних епізодів. Вступаючи до мистецького діалогу 3 великим попередником, Й. Маркс акцентує увагу на інших його творчих знахідках: жанрі симфонічної поеми та принципі монотематизму.

3 жанрово-композиційної точки зору «Рапсодія» Й. Маркса є камерно-інструментальним аналогом симфонічної поеми, якій притаманне «об’єднання в одночастинності рис сонатного allegro та сонатносимфонічного циклу. Основна частина симфонічної поеми зазвичай

Існують й інші записи окремих частин даного твору Й. Маркса. Так, «Балада» була записана у 2013 р. ансамблем «Trio Alba» (Livia Sellin, скрипка, Philipp Comploi, віолончель, Chengcheng Zao, фортепіано, а також Wen Xiao Zheng, скрипка). «Рапсодія» була записана у 2012 р. Нью-Йоркським фортепіанним квартетом (New York Piano Quartet) у складі Elmira Darvarova, скрипка, Ronald Carbone, альт, Samuel Magill, віолончель, та Linda Hall, фортепіано.

${ }^{1}$ Безперечно, грандіозні масштаби кожної з частин Квартету цілком дозволяють виконувати їх окремо. Крім того, у творчості Й. Маркса часто зустрічаємо прецеденти авторського відокремлення частин від єдиного циклічного цілого (наприклад, остання частина «Осінньої симфонії» «Ein Herbstpoem» («Поема осені») отримала самостійне концертне життя). Можливо, саме цією особливістю мислення Й. Маркса пояснюється різниця у формулюваннях назв частин квартету.

${ }^{2}$ Варто додати, що це не єдине звернення Й. Маркса до романтичних жанрів балади та рапсодії: в його доробку знаходимо «Рапсодію» та «Баладу» 3 циклу «Шість п’єс для фортепіано» (1916), а також симфонічну «Nordlands-Rhapsodie» (1928-29). 
складає ряд різнохарактерних епізодів, які з точки зору сонатного allegro відповідають головній партії, побічній партії та розробці, а $з$ точки зору циклу - першій (швидкій), другій (ліричній), i третій (скерцо) частинам» [12, с. 18]. Також в «Рапсодії» Й. Маркс послідовно застосовує принцип монотематизму: інтонаційно та жанрово багатогранна тема головної партії не лише виступає джерелом усіх тем даної частини: iï інтонації проникають в музичну тканину «Скерцо» та «Балади» і у такий спосіб об'єднують весь цикл квартету.

Розгорнута епічна головна тема-епіграф «Рапсодії» (див. Приклад № 1) викладена в унісон в партіях струнних та включає цілий ряд інтонаційножанрових витоків. Чітка маршева ритміка поєднується в ній 3 плинною кантиленою та висхідним романсовим секстовим зворотом. Особливо важливим є квінтовий мотив у другому такті теми: саме він виступатиме тим «цементуючим», об’єднавчим інтонаційним елементом, що винятково сприятиме єдності циклу. Ритмічна свобода та виразні «ораторські» паузи на початку теми свідчать про присутність оповідного, декламаційного начала, притаманного рапсодії як епічному жанру. В останніх тактах теми 3'являється скерцозний елемент, що відіграватиме важливу роль наприкінці частини. Отже, тут присутні епіко-драматичне (речитатив), ліричне (романсова кантилена) та танцювальне (скерцо) жанрові начала, що робить тему справді універсальним інтонаційним джерелом для всього циклу.

\section{Тема головної партії «Рапсодії»}

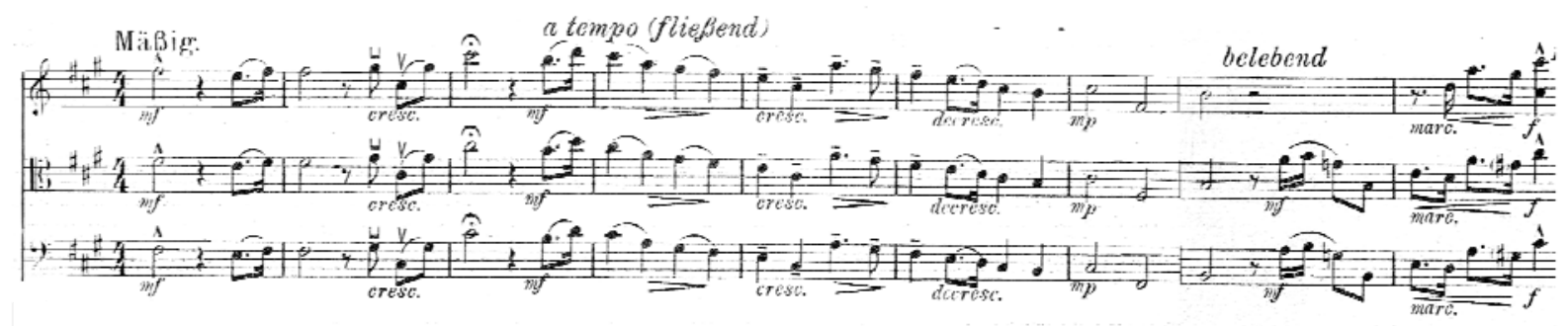

Мотивній та поліфонічній розробці теми головної партії присвячений весь перший розділ «Рапсодії» («сонатне allegro», літери $A-$ $G)$. Й. Маркс демонструє значну поліфонічну майстерність, комбінуючи елементи теми в канонах та імітаціях, проводячи iii y фактурному збільшенні та зменшенні. У початковому розділі «Рапсодії» Й. Маркс трактує фортепіанну фактуру «крупним мазком», як носія насиченої, масштабної акордової тканини. В цьому спостерігається близькість до творчих почерків Й. Брамса, С. Франка, М. Регера та ін. Натомість фактура партій струнних інструментів свідчить про більш індивідуалізовану, мелодико-лінеарну, поліфонічну розробку тематизму. 
Другий розділ «Рапсодії» (літери $G-S$ ) виконує роль повільної частини («adagio»). Тут Й. Маркс використовує лістівський прийом жанрової трансформації теми: побічна партія (літера $G$ ) фактично $є$ «ліризованою» темою головної партії, викладеною в субдомінантовій тональності $h$-moll, уповільненою та позбавленою чіткого пунктирного ритму (див. Приклад № 2):

Приклад № 2

\section{Тема побічної партії «Рапсодії»}

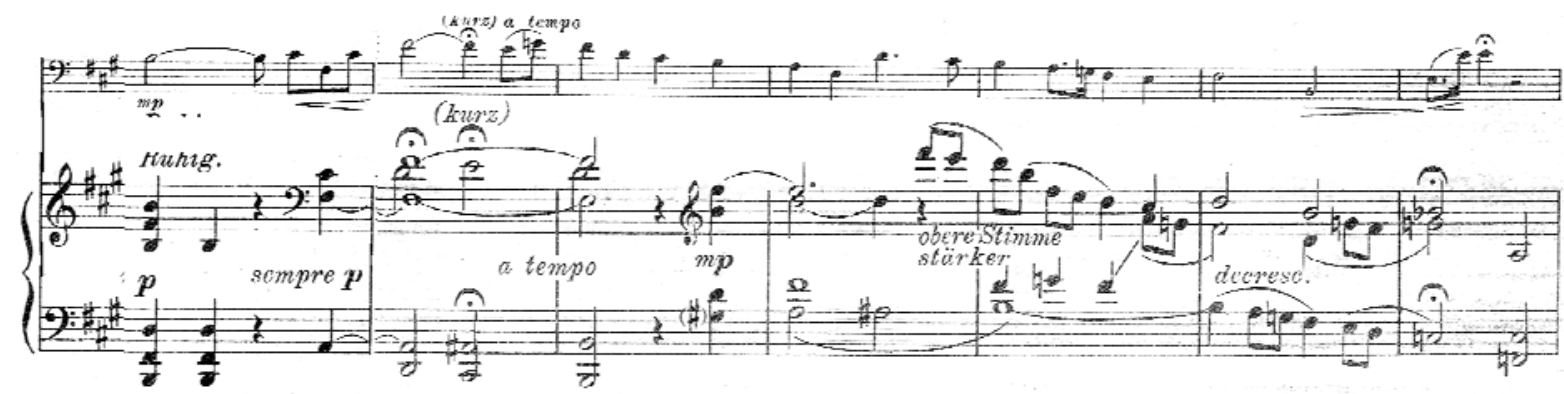

Наступний повільний розділ «Рапсодії» являє собою самостійну «внутрішню» сонатну форму: вищенаведена тема побічної партії виступає тут «локальною» темою головної партії. Згодом у партії віолончелі постає нова тема (літера $K, e$-moll), також споріднена з темою-епіграфом «Рапсодії» через романсову, кантиленну природу мелодики, підкреслену малосекундову інтонацію зітхання та виразний висхідний секстовий зворот.

Дана тема виконує роль побічної партії даного розділу «Рапсодії» (див. Приклад № 3), де цілком втілився дар Й. Маркса - глибокого, проникливого лірика та філософа. Неспішність розгортання, замилування красою кожного звуку та мелодичного звороту, виняткова прозорість фактури, наділення партії кожного з інструментів яскравими монологічними сольними епізодами - цей розділ відбиває творчий дар Й. Маркса як майстра Lied, лаконічного, задушевно-ліричного музичного висловлювання.

\section{Побічна партія повільного епізоду «Рапсодії»}

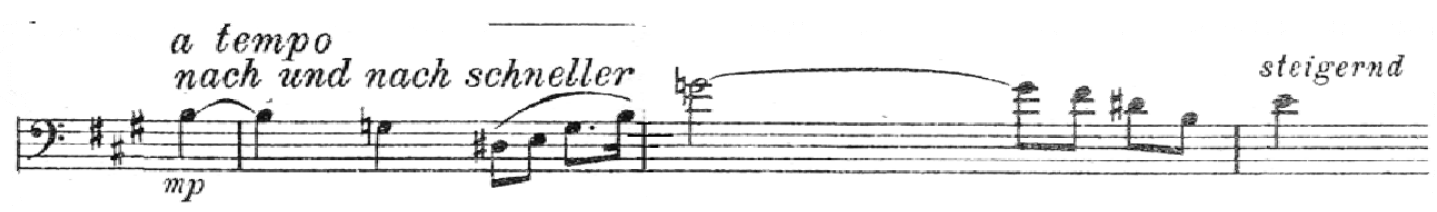

Репризний розділ «Рапсодії» (літери $S-U$ ) зовсім невеликий і дещо «формальний», адже повернення головної теми (літера $T$ ) $€$ лише передіктом перед заключним, четвертим епізодом твору (літери $U-Z$ ). Відокремлений генеральною паузою, фінал «Рапсодії» складає абсолютний образно-смисловий та фактурно-стильовий контраст до всього 
попереднього матеріалу. Тут Й. Маркс ставить перед собою за мету перевтілення масштабного, концертного лістівського піанізму. «Класичний» квартетний ансамбль брамсівського типу 3 його лірикодраматичним, філософським пафосом, індивідуалізованим трактуванням партій, лінеарністю та поліфонічністю фактурного мислення одразу перетворюється на «міні-оркестр» 3 багатими колористичними, звуконаслідувальними тембральними можливостями. Це цілком відповідає творчим принципам Ф. Ліста, який намагався збагатити звучання фортепіано оркестровими тембрами, «для більш опуклої та яскравої передачі драматичних та динамічних моментів широко використовував оркестрові ефекти тремоло, акордові трелі чи октави martellato» [3, с. 198].

Заключний розділ «Рапсодії» - по суті, кода грандіозних масштабів. За типологією К. Ручьєвської, це «кода-процес, прагнення до мети, кода біг до кінцевої точки розвитку», для якої притаманне «розчинення рельєфу у фігураціях, застосування різних інерційних прийомів розвитку», замкнений рух типу «кружляння» $[10$, с. $180-181]$. Тут постають прямі алюзії на «улюблені» лістівські жанри фантастичного скерцо, віртуозної тарантели та концертного етюду. Саме у заключному розділі реалізований активний імпульс скерцо, вперше поданий у двох останніх тактах головної теми.

«Рапсодія» для фортепіанного квартету $є$ витонченим мистецьким діалогом 3 композиторською спадщиною Ф. Ліста: Й. Маркс акцентує увагу на жанрових, композиційних та фактурних знахідках свого попередника. Цікавим $є$ використаний прийом своєрідного «переоркестрування» камерного ансамблю, переведення його на фактурні рейки «сольного» інструменту - фортепіано. Це робить «Рапсодію» твором, винятково складним для виконавців (не в останню чергу через тривалість звучання - 28 хвилин), від яких вимагається надзвичайна монолітність, «зіграність» ансамблю. Надзвичайно важливою $\epsilon$ спроможність одночасно переключатися між різними фактурними епізодами та разом вибудовувати загальну драматургію твору.

За словами К. Шлюрена, «Скерцо» $d$-moll для фортепіанного квартету «викладене у масштабах, що найкраще визначаються через критерій розгорнутих симфонічних скерцо пізньої та пост-романтичної ери (Брукнер, Малер та Шмідт)» [19, с. 15]. Рондальна композиція цієї частини Квартету заснована на контрастному чергуванні двох темобразів: жвавого, грайливого, дещо імпресіоністичного скерцо та суворої, монолітної унісонної теми, що перевтілює величезний пласт героїкодраматичних тем від Бетховена до Брамса. Перша тема-рефрен (див. Приклад № 4) скоріше відіграє роль вступу: композиційно 
розгорнута, багатокомпонентна і мінлива, вона виступає основним носієм жанрових ознак скерцо, серед яких - «швидкий темп, вільна зміна музичних думок, що вносить елемент несподіваного, раптового $<\ldots>$, від веселої гри, жарту до гротеску» [13]. Нагадаємо, що скерцозність у даному циклі також веде своє походження з головної теми «Рапсодії».

Приклад № 4

\section{Перший рефрен «Скерцо»}

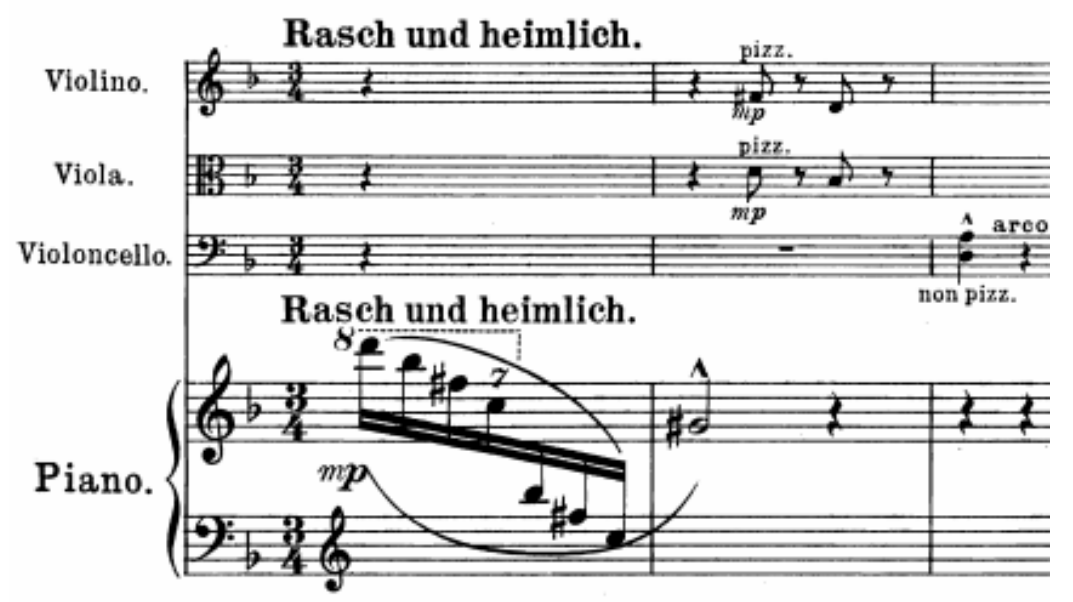

Другий рефрен скерцо (d-moll), що експонується у партії фортепіано 3 канонічною відповіддю струнних, - це «тема, повністю завершена i замкнена», що «поєднує в собі ознаки головної, початкової і завершальної, узагальнюючої тем» [2, с. 161] (див. Приклад № 5).

Приклад № 5

\section{Другий рефрен «Скерцо»}

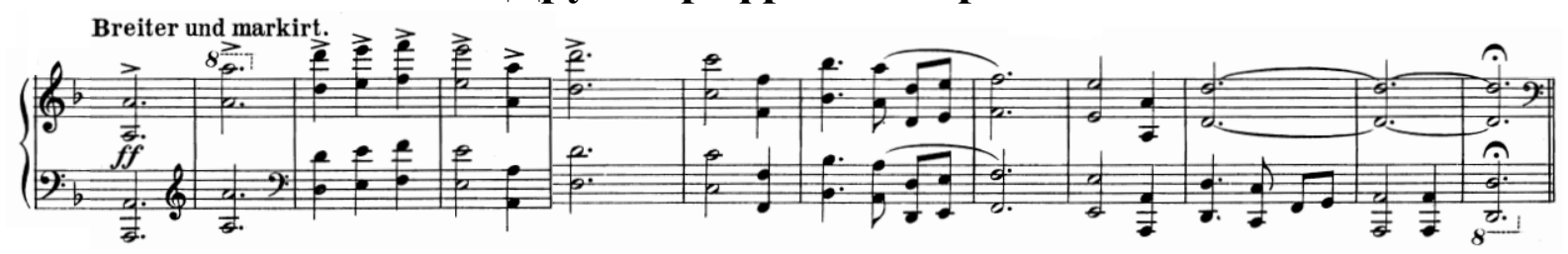

Могутній октавний зачин, чітка ритміка, плавний рух мелодики (за типом протестантського хоралу), суворі унісони, опора на стійкі ступені тональності - такі характеристики включають до себе і тема Скерцо № 2 Ф. Шопена, і «давидсбундлерівські» образи Р. Шумана, і тема головної партії «Богатирської симфонії» О. Бородіна тощо. Саме в другій темі постає своєрідний тридольний «лейтритм», що стане ритмічним імпульсом всіх епізодів «Скерцо». Однологосна фактура, монолітність унісонного звучання, рішучий маршевий пунктир, а також підкреслена квінта у 4 та 9 тактах поєднують другий рефрен «Скерцо» $з$ головною темою «Рапсодії». 
У наступному розділі (літера $B$ ) розпочинається активний поліфонічний розвиток другого рефрену. Й. Маркс використовує елементи барокової стилістики, зокрема - «токатне» протискладення у струнних (літера $B+11$ тактів, див. Приклад № 6). Масштабного «органного» звучання фактурі надає акордовий хоральний супровід у партії фортепіано.

Приклад № 6

\section{Фрагмент «токатного» протискладення} до теми-рефрену «Скерцо»

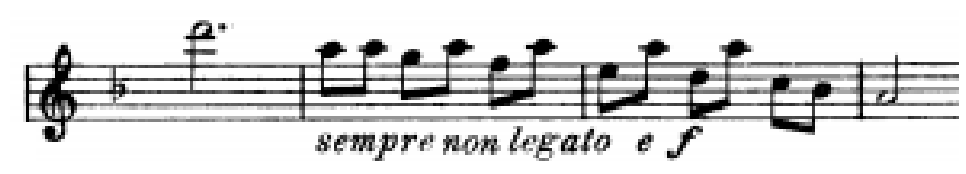

Спираючись на обидва рефрени, Й. Маркс неспішно виплітає музичну тканину «Скерцо». У розділі під літерою $G+21$ такт композитор вводить новий епізод: у заповільненому темпі у скрипки solo з прозорим супроводом фортепіано та pizzicato альта й віолончелі неспішно лунає елегантний віденський вальс. Виникає майже кінематографічний ефект «наближення», «стоп-кадру»: зі світу активної інтелектуальної гри (перший рефрен) та драматичного пафосу (другий рефрен) автор несподівано «перемикає» нас на суто побутову картину сьогодення. Тим яскравіше звучить раптове повернення суворої «барокової» другої теми (літера $K$, fis-moll, ff), що ніби нагадує про швидкоплинність миті душевного спокою та гармонії.

Велика кода (літера $N$ ) являє собою цілковиту зону crescendo accelerando, заснованої на остинатних повтореннях пружного тридольного мотиву, похідного від другої теми. Попри очікування, Й. Маркс не завершує «Скерцо» на заключних урочистих акордах D-dur: після чотиритактової (!) генеральної паузи 3 майстерністю кінорежисера композитор включає ще один «вставний» епізод - невелике Тріо $B$-dur. I знову відчувається музичний дух Відня: лагідні терцієві мелодичні «погойдування» викликають аналогії 3 шубертівською «Колисковою струмка». Тріо перетворює рондо «Скерцо» на форму da саро (авторська ремарка - «зі сторніки $18, F \gg)$. Гра образів розпочинається знову...

За словами Бориса Асаф'єва, у скерцо «поряд 3 дієвістю та спогляданням виникали ігрові та танцювальні дозвілля людства» [1, с. 22]. $\mathrm{y}$ «Скерцо» Й. Маркса синтез пластів сягає більш глибокого рівня. Як представник пізнього, завершального періоду він осягає всю попередню епоху романтизму як своєрідну художню цілісність. Як зазначає Л. Неболюбова, «в результаті процесуальне ціле <..> може справляти враження внутрішньої неоднорідності, незв'язності, образно-стильової 
клочкуватості, що на практиці, в реальному побутуванні <..> часто сприймається як недолік та позначається як еклектичність» [7, с. 61]. У «Скерцо» для фортепіанного квартету Й. Маркс вільно оперує різностильовими елементами від бахівської поліфонії та віртуозного романтичного скерцо до наспівності австро-німецької Lied та «прикладної» музики віденської кав'ярні.

Фортепіанний квартет Й. Маркса завершує суворо-споглядальна «Балада» a-moll. Написана в «класичній» сонатній формі, вона композиційно стрункіша порівняно з попередніми частинами. В циклі вона виконує функцію повільної частини i, водночас, своєрідного філософського епілогу.

Порівняно $з$ попередніми частинами, у «Баладі» найбільш яскраво втілилася необарокова лінія творчості Й. Маркса. Майстерна поліфонічна «гра» $\epsilon$ музичною даниною Й. С. Баху, адже для Й. Маркса, як і для Й. Брамса та М. Регера, типовим є «відчуття музики Баха, Моцарта, Бетховена, Шуберта, Шумана як витоку та вищого, недосяжного ідеалу» [15].

«Баладу» відкриває експозиція дванадцятитактової теми головної партії. Як і в «Рапсодії» та «Скерцо», головна тема «Балади» викладена в «графічній» одноголосній фактурі. Аскетично-сувора i зосереджена, лірично-скорботна мелодія містить виразні секстові романсові інтонації, що викликають певні алюзії 3 мелодикою шубертівського циклу «Зимовий шлях» (див. Приклад № 7). Чітка регулярна ритмічна пульсація нагадує про бахівську «кроковість». Особливо тонкої, філігранної виразності темі надає виконавський штрих: Й. Маркс використовує тут короткі «дуольні» ліги. Самотньо і тихо одноголосна тема лунає у партії віолончелі (a-moll), даючи початок фугато у виконанні струнного тріо, що досягає своєї кульмінаційної точки з могутнім унісонним вступом теми у партії фортепіано (літера $A$ ).

Приклад № 7

\section{Порівняння головної партії «Балади» 3 «Gute Nacht»} («На добраніч» або «Спокійно спи» 3 «Зимового шляху» Ф. Шуберта)

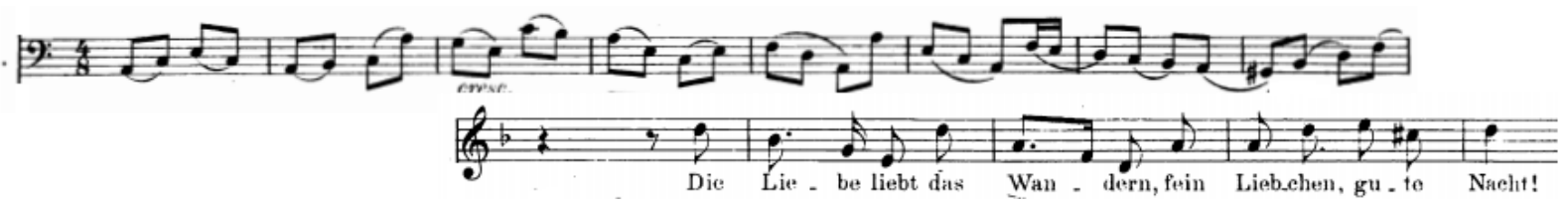

Немов раптове прояснення, в однойменному $A$-dur звучить невелика сполучна партія, доручена фортепіано. Її м'які інтонації готують появу теми побічної партії (літера $B, D$-dur), яка наче переносить нас з лірикофілософського світу головної теми до вибагливих і граційних образів віденського сецесіону (див. Приклад № 8). 
Приклад № 8

\section{Тема побічної партії «Балади»}

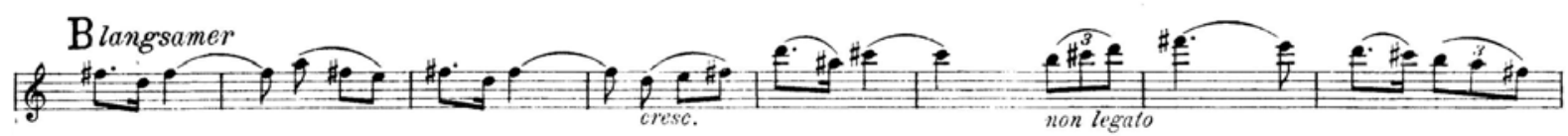

Витончене, тремтливе соло скрипки, легкі акорди фортепіанного супроводу, вільна ритмічна структура у поєднанні з лагідними терцієвими інтонаціями - все це створює значний стильовий контраст 3 аскетичним центральним образом. Мелодичні «погойдування» терцій нагадують ніжну колискову Тріо зі «Скерцо». Просвітлений ліризм притаманний і заключній партії «Балади». В останніх тактах експозиції лунає радісне скерцо.

Інтонаційною основою розробки виступає тема головної партії, що піддається різноманітним типам поліфонічного розвитку, чому надзвичайно сприяє іiі лінеарно-мелодична природа. Серед інших частин Квартету розробку «Балади» вирізняє чіткість і ясність побудови, відсутність улюблених Й. Марксом «вставних» фрагментів, що обтяжують та розширюють композицію. Так, перший епізод розробки (літера $D, d$-moll) заснований на послідовному імітаційно-канонічному проведенні головної теми. Контрастом до насиченої «хорової» фактури та динамічного руху початкового розділу лунає другий епізод розробки: прозорий дует віолончелі (згодом альта) та фортепіано у заповільненому темпі (ремарка «langsamer und leise») проводить фрагмент головної теми, що звучить наче голос 3 «іншого світу», як тиха малерівська Lied. Третій епізод (літера $F$ ) відновлює суворий невпинний поступ фугато (c-moll), в образну орбіту якого залучається навіть побічна (літера G, Markiert, четвертий епізод розробки): вона жанрово трансформується, перетворюючись на драматичний марш-скерцо.

Кульмінаційний розділ розробки (літери $I-M$ ) позначений значною кількістю використаних поліфонічних прийомів: головна тема лунає в одночасному фактурному збільшенні та зменшенні, в контрапункті 3 побічною, насичується секвентним та мотивним розвитком тощо. Стрімкий рух охоплює всі пласти фактури, що якнайкраще відбиває ідейний задум «Балади» - втілення дієвого, неспокійного життя людського творчого духу.

Реприза одночасно виступає найвищою точкою розробки: величним проголошенням Істини лунає повернення головної теми, викладеної унісоном струнних 3 акордовою підтримкою фортепіано. Основну роль наприкінці «Балади» відіграє побічна тема: іiі лагідний, гармонійний образ приходить на зміну динамічному драматизму головної партії. Ліричною 
післямовою постає невелика кода, де ідилічні мотиви побічної поступово розчиняються у супроводі легких арпеджіо фортепіано.

«Балада» для фортепіанного квартету найбільш повно втілює в собі глибинні зв'язки творчості Йозефа Маркса 3 мистецтвом бароко та класицизму. Про це свідчить чіткість та ясність композиції, традиційне для сонатної форми контрастне образно-смислове поєднання головної та побічної партії, широке використання прийомів поліфонічного та мотивного розвитку тощо. 3 романтичним жанром балади твір Й. Маркса єднає епічна оповідність тону та неспішність драматургічного розгортання. Водночас «Балада» для фортепіанного квартету не має нічого спільного 3 програмністю, типовою для цього жанру в його численних романтичних перевтіленнях: можна сказати, що це своєрідна «балада» людської душі 3 iï неспішними роздумами про прекрасне минуле та спокійно-зосередженим спогляданням сучасності.

Отже, Фортепіанний квартет Й. Маркса $є$ яскравим твором перехідної, зламної доби перших десятиліть ХX ст., однією зі стильових домінант якої був пізній романтизм. Завершальна, синтетична природа пізнього романтизму втілилася в Квартеті через шанобливе ставлення до музичної спадщини від Баха до Брамса, і водночас - у вільному оперуванні елементами різних музичних стилів. Композитор демонструє альтернативний погляд на мистецтво: його метою є дбайливе оберігання $\mathrm{i}$ культивування прекрасних надбань мистецтва минулого, що постає не лінійно, а у своїй найширшій «одномоментній» панорамі: бахівська поліфонія та протестантський хорал для Й. Маркса не менш животрепетні, ніж віртуозний піанізм Ф. Ліста, а шубертівська мелодика вільно поєднується 3 колористичним звукописом в дусі К. Дебюссі. Все це невід'ємні складові музичної мови Й. Маркса, органічні частки його «генетично-зумовленого» композиторського мислення. При цьому композитору вдається уникати враження еклектизму і несмаку: основним об'єднавчим критерієм виступає тісний інтонаційний взаємозв'язок всіх тематичних елементів циклу.

Властиві пізнім періодам «передбачення майбутнього» у Й. Маркса менш очевидні: на рівні музичної мови він все ще знаходиться у «силовому полі» романтизму. 3 музикою ХХ століття квартетний опус Й. Маркса споріднює порівняна свобода композиційного мислення: композитор поєднує різнохарактерні епізоди, не зважаючи на певну часову «розтягненість» та зовнішню асиметричність побудови. Величезні масштаби композиції, iї епічний розмах, неспішність розгортання $\epsilon$ суто індивідуальною ознакою композиторського мислення Й. Маркса. При цьому 
діє залізна логіка драматургічного, часом майже «сюжетного» розвитку, за рахунок чого долається враження безформності та хаотичності.

Значним здобутком Й. Маркса є об’єднання трьох розгорнутих, цілком придатних для самостійного концертного існування частин у величезний квартетний цикл. Це здійснено, передусім, за рахунок потужних інтонаційних зв'язків між частинами: універсальним джерелом більшості тем «Скецо» та «Балади» виступає тематизм «Рапсодії», що містить в собі епічно-речитативне, лірично-романсове та танцювально-скерцозне начало. Не менш важливими є композиційно-драматургічні аналогії між частинами. Так, спільним драматургічним прийомом є контрастне поєднання епікодраматичної, аскетично одноголосної головної теми та чуттєво-ліричної, «по-штраусівськи» вишуканої побічної. Розробкові епізоди всіх трьох частин побудовані на інтенсивному мотивно-поліфонічному розвиткові головних тем та містять контрастні вставні епізоди образного темповочасового «відсторонення», що значно розширюють загальну композицію. У репризних розділах особливого значення набуває кода, що виступає як ліричною післямовою, так і яскравим віртуозним фіналом.

Виконання Фортепіанного квартету Й. Маркса - непросте завдання для будь-якого ансамблю. Фактура твору дуже зручна і придатна для виконання: відчувається глибинне знання композитором специфіки гри на кожному з інструментів. Роботу музикантів композитор регулює великою кількістю ремарок: цілком очевидно, що вони $є$ результатом особистого виконавського досвіду.

Складність виконання Квартету полягає, передусім, в інтелектуальному осягненні його багатоскладової композиції - зовні неоднорідної, асиметричної, навіть дещо рихлої, однак насправді охопленої залізною логікою. Вишукана пізньоромантична гармонічна мова, мелодичне багатство, фактурна винахідливість та концепційна глибина не дозволяють думати, що перед нами - твір композиторапочатківця, автодидакта, яким був на момент створення «Рапсодії», «Скерцо» та «Балади» 29-річний Йозеф Маркс.

Фортепіанному квартету Й. Маркса, користуючись влучним висловом Костянтина Зєнкіна, властиве «виняткове багатство та різноманіття форм, що відповідає останньому, витончено-вишуканому прояву творчої фантазії напередодні осіннього в'янення» [4, с. 130].

1. Арановский М. Симфонические искания. Проблема жанра симфонии в советской музыке 1960-1975 годов: исследовательские очерки. Ленинград: Советский композитор, 1979. 285 с. 
2. Бобровский В. Функциональные основы музыкальной формы. Москва : Музыка, 1978. 332 c.

3. Друскин М. История зарубежной музыки второй половины XIX века. Выпуск четвертый. Москва : Музыка, 1967. 519 с.

4. Зенкин К. В. Фортепианная миниатюра и пути музыкального романтизма. Москва : Московская государственная консерватория имени П. И. Чайковского, 1997. 509 с.

5. Клусон Ю. Некоторые проблемы художественной культуры Австрии и творчество нововенцев в 1918-1938 годы // Проблемы истории австро-немецкой музыки. Первая треть ХХ века : сборник трудов. Вып. 70. Москва, 1983. С. 25-34.

6. Крейнина Ю. Регер и мастера XX века // Проблемы истории австро-немецкой музыки. Первая треть XX века : сборник трудов. Вып. 70. Москва, 1983. С. 104-116.

7. Неболюбова Л. Системно-стилевые проблемы австро-германского романтизма (типология поздних этапов в истории искусства) // Исторические и теоретические проблемы музыкального стиля : темат. сб. науч. трудов. Киев, 1993. С. 55-70.

8. Рапсодия // Музыкальная энциклопедия. Т. 4. Москва : Советская энциклопедия, 1978. C. 540-541.

9. Русакова Л. Модернізм : тлумачення у вітчизняному музикознавстві // Проблеми взаємодії мистецтва, педагогіки та теорії і практики освіти : зб.наук.ст. Вип. 34 / Харк. нац ун-т мистецтв імені І. П. Котляревського. Харків : Вид-во С.А.М., 2012. С. 86-102.

10. Ручьевская Е. Классическая музыкальная форма: Учебник по анализу. СанктПетербург : Композитор, 2004. 300 с.

11. Ручьевская Е. Об анализе содержания музыкального произведения // Е. А. Ручьевская. Работы разных лет. Том 1 : Статьи. Заметки. Воспоминания. Санкт-Петербург : Композитор, 2011. С. 291-321.

12. Симфоническая поэма // Музыкальная энциклопедия. Т. 5. Москва: Советская энциклопедия, 1981. С. 17-19.

13. Скерцо // Музыкальная энциклопедия. Т. 5. Москва : Советская энциклопедия, 1981. C. $49-50$.

14. Царева Е. М. Баллада // Музыкальная энциклопедия. Т. 1. Москва: Советская энциклопедия, 1973. С. 308-309.

15. Haydin B. Biography \& Personality // Josef Marx : web-site. URL: http://www.josephmarx.org/en/biography.html\#biography (access date: 12.10.2017).

16. Haydin B. Who was Joseph Marx? // Josef Marx : web-site. URL: http://www.josephmarx.org/documents/biography-new.html (access date: 12.10.2017).

17. Liess A. Joseph Marx. Leben und Werk. Mit einem Titelbild, 12 Bildern im Text und 24 Notenbeispielen. Graz : Steirische Verlagsanstalt, 1943. 247 s.

18. Pauls H. Two centuries in one. Musical Romanticism and the twentieth century: $\mathrm{Ph} . \mathrm{D}$. thesis / Rostock University of Music and Theatre; McNally Robinson. Rostock, 2014. $475 \mathrm{p}$.

19. Schlüren Ch. Post-Romantic Impressionism from Styria: CD booklet // Joseph Marx (1882-1964). Works for piano quartet (1911). München : Bayerischer Rundfunk, 2010. 19 p.

\section{References}

1. Aranovskiy, M. (1979). Symphonic searches. The problem of the symphony genre in Soviet music of 1960-1975: research essays. Leningrad: Sovetskiy kompozitor [in Russian].

2. Bobrovskiy, V. (1978). Functional foundations of musical form. Moscow: Muzyka [in Russian]. 
3. Druskin, M. (1967). History of foreign music of the second half of the nineteenth century. Fourth part. Moscow: Muzyka [in Russian].

4. Zenkin, K. (1997). Piano miniature and the path of musical romanticism. Moscow: Moscow State Tchaikovsky Conservatory [in Russian].

5. Kluson, J. (1983). Some problems of the artistic culture of Austria and the creation of the Second Viennese School in 1918-1938. Problemy istorii avstro-nemetskoy muzyki. Pervaya tret XX veka, 70, pp. 25-34 [in Russian].

6. Kreynina, Y. (1983). Reger and masters of the twentieth century. Problemy istorii avstronemetskoy muzyki. Pervaya tret XX veka, 70, pp. 104-116 [in Russian].

7. Nebolyubova, L. (1993). System-style problems of Austro-German romanticism (typology of the late stages in the history of art). Istoricheskiye $i$ teoreticheskiye problemy muzykalnogo stilya, pp. 55-70 [in Russian].

8. Rhapsody (1978). In: Musical Encyclopedia. Vol. 4. Moscow: Sovetskaya entsiklopediya, pp. 540-541 [in Russian].

9. Rusakova, L. (2012). Modernism: interpretation in domestic musicology. Problemy vzayemodiyi mystetstva, pedahohiky ta teoriyi i praktyky osvity, 34, pp. 86-102 [in Ukrainian].

10. Ruchyevskaya, Y. (2004). Classical musical form. Analysis Tutorial. Saint-Petersburg: Kompozitor [in Russian].

11. Ruchyevskaya, Y. (2011). On the analysis of the content of a musical work. In: Y. Ruchyevskaya. Works of different years. Vol. 1. Articles. Notes. Memories. SaintPetersburg: Kompozitor, pp. 291-321 [in Russian].

12. Symphonic poem (1981). In: Musical Encyclopedia. Vol. 5. Moscow: Sovetskaya entsiklopediya, pp. 17-19 [in Russian].

13. Scherzo (1981). In: Musical Encyclopedia. Vol. 5. Moscow: Sovetskaya entsiklopediya, pp. 49-50 [in Russian].

14. Tsarova, Y. (1973). Ballad. In: Musical Encyclopedia. Vol. 1. Moscow: Sovetskaya entsiklopediya, pp. 308-309 [in Russian].

15. Haydin, B. (n.d.). Biography \& Personality. [online] Josef Marx. Available at: http://www.joseph-marx.org/en/biography.html\#biography [Accessed 12 October 2017] [in English].

16. Haydin, B. Who was Joseph Marx? [online] Josef Marx. Available at: http://www.josephmarx.org/documents/biography-new.html [Accessed 12 October 2017] [in English].

17. Liess, A. (1943). Joseph Marx. Leben und Werk. Mit einem Titelbild, 12 Bildern im Text und 24 Notenbeispielen. Graz : Steirische Verlagsanstalt [in German].

18. Pauls, H. (2014). Two centuries in one. Musical Romanticism and the twentieth century. $\mathrm{PhD}$ thesis. Rostock University of Music and Theatre [in English].

19. Schlüren, Ch. (2010). Post-Romantic Impressionism from Styria. [CD booklet] In: Joseph Marx (1882-1964). Works for piano quartet (1911). München: Bayerischer Rundfunk [in English]. 